\title{
AHP Metoduyla Yer'e Özgü Mimari Tasarım Kriterlerinin Öncelik Sırasının Belirlenmesi
}

\author{
Emine YILDIZ KUYRUKÇU*1, Ahmet ALKAN² \\ 1,2Konya Teknik Üniversitesi, Mimarlık ve Tasarım Fakültesi, Mimarlık Bölümü, 42030, Konya, Türkiye \\ 1(ORCID: https://orcid.org/0000-0002-5794-3507) \\ 2 (ORCID: https://orcid.org/0000-0002-9244-819X)
}

(Alınış / Received: 24.02.2019, Kabul / Accepted: 18.03.2019, Online Yayınlanma / Published Online: 19.03.2019)

Anahtar Kelimeler Mimari tasarım, Yere özgü tasarım, Eleștirel rejyonalizm, Kenneth Frampton, AHP
Özet: 20. yüzyılda küreselleşme ile mimari tasarımın yerle olan ilişkisi kopmuş, her türlü bölgesel sınır ortadan kalkmıştır. Bu bağlamda mimarlık, bölgesel bir olgu olmaktan çıkmış, artık sınırları olmayan evrensel bir olgu haline gelmiştir. Çalıșma, 'mimari tasarım-yer' ilişkisini doğru kurmanın yani yerin ruhunun somutlaştırılmasının yolu olarak Eleștirel Bölgeselciliğin çözüm olabileceğini savunmaktadır. 'Eleştirel Bölgeselcilik (Critical Regionalism)' yaklaşımında 'yer'e ait değerlerle, çağdaş yer yönelimli tasarım yapmak amaçlanmaktadır. Çalışma kapsamında Eleştirel Bölgeselcilik kavramını geliştiren Kenneth Frampton'ın 1987'lerde söylemleștirdiği 10 maddesi yorumlanarak dokuz kriter belirlenmiş ancak bu kriterlerin günümüz koşullarında yetersiz olduğu düşünülerek tarafımızdan dört kriter eklenerek "bir yapıyı eleştirel rejyonalist-o yer'e (bölgeye) ait" olarak nitelendirebilmenin on üç evrensel kriteri, dört grup halinde ortaya konulmuştur. Çalışmanın asıl amacı bir yapının eleştirel rejyonalist-o yer'e (bölgeye) ait olarak adlandırılabilmesi için hangi kriterlerin etken olduğu ve bu kriterlerin öncelik sıralamasını tespit etmektir. Bu doğrultuda doktor unvanına sahip Selçuk Üniversitesi, Gazi Üniversitesi, Orta Doğu Teknik Üniversitesi'nden Restorasyon Anabilim Dall, Mimarlık Tarihi Anabilim Dalı, Bina Bilgisi Anabilim Dalında görevli toplam 34 uzmandan, bir tasarımın o yere ait olarak alglanmasında belirlenen kriterlerin ne kadar etken olduklarını puanlamaları istenmiştir. Sonuçlar AHP (Analitik Hiyerarşi Prosesi) metoduyla analiz edilmiş ve çalışma kapsamında ortaya konulan kriterlerin geçerliliği ve tüm bu kriterlerin öncelik sırası belirlenerek "bir yapıyı eleştirel rejyonalist-o yer'e (bölgeye)" ait olarak nitelendirmede öncelikli kriterler tespit edilmiştir.

\section{Determination of the Priority Order of Place-Specific Architectural Design Criteria by AHP Method}

\section{Keywords}

Architectural design, Place-specific design Critical regionalism, Kenneth Frampton, AHP

\begin{abstract}
In the 20th century, the relationship between globalization and architectural design had been broken down and all regional borders was eliminated. In this context, architecture has ceased to be a regional phenomenon and has become a universal phenomenon with no boundaries anymore. The study advocates that critical regionalism can be a solution as a way of embodied the spirit of the place, establishing the 'architectural design-place' relationship correctly. In the 'Critical Regionalism' approach, it is aimed to design contemporary place-oriented with the values of 'place'. In the scope of study, the ten points voiced by Kenneth Frampton in 1987 is interpreted and nine criteria are designated, however after conceiving these criteria are inadequate in present conditions, four more criteria are added and the thirteen universal criteria of being able to qualify "a structure as critical regional - a belonging to that place (region)" have been demonstrated in four groups. The main aim of this study is to determine, which criteria are eligible to name a structure as critical regional (a belonging to that place) and the priority ranking of these criteria. Within this context, $34 \mathrm{Dr}$. titled experts who are from Restoration Department, Architecture History Department and Building Knowledge Department of Selcuk University, Gazi University and Middle East Technical University were asked to score how much the determined criteria are influential in perceiving a design's belonging to that place. Results were analyzed with AHP (Analytical Hierarchy Process) method and the priority criteria have been identified in determining " $a$ structure as a belonging to that place (region) - as critical regional", after designating the validity of the principles set forth in the scope of the study and the priority of all these criteria.
\end{abstract}




\section{Giriş}

Mimari eser 'yer' le başlar. Mimarlıkta yer kavramı, çoğu zaman, mimari tasarımı biçimlendiren ya da biçimlendirmesi gereken temel etmenlerden biri olarak değerlendirilmektedir. Mimari, yer ile birlikte vardır. Yer mimariyi kurmakta, mimari de yeri dönüştürmektedir. 'Yer' kavramı mimaride belirleyici rol oynayan ve yapıyı 'anlamlı' kılan bir özelliktir. Mimari tasarım, yeri ile uyumlu olduğu sürece başarılı sayılmaktadır. Yalıtılmış bir kavram olarak yer/mekân (içinde insani yaşam barındıran oluşum), tek başına anlamsızdır. Yer'in mimariyle bütünleşmesi, tümel bir gerçeklik olarak ele alındığında, çevresindeki olgularla anlamlı biçimde ilişkiyi sağlayan bileşenlerin sürece dâhil olmasıdır. $\mathrm{Bu}$ bileşenler tüm doğal, yapay, sosyal, psikolojik, politik, ekonomik, tarihsel, kültürel verileri içermektedir. Mimari dil, yerin zaman içinde kendini ifade etme biçimi ise bu ifade biçimi, "yer"le kurulan yaşamsal ilișkinin, her defasında bir önceki olușumla yeniden anlam kazanması, onunla ilişki kurmasıdır. Norberg-Schulz [1] mimari tasarım-yer ilişkisini şöyle özetler: "Mimarlık, bütüncül bir çevrenin görünür kılınmasıdır... Genel anlamda bu, yerin ruhunun somutlaştırılması demektir... Mimarlığın görevi anlamlı yerler yaratmaktır. Böylece insanın mesken tutmasını sağlamaktır." Mimarlık Abel [2]'in belirttiği gibi, eğer bir çeşit varoluş biçimiyse, bu noktada "yer" insanın varlığı ekseninde ontolojik bir boyut kazanmaktadır. Mimarlık disiplini insanın yer ile kurduğu ilişkiyi yansıtan bir aracı konumundadır.

Tüm süreçte insanın 'yer'e iliş̧kin algısının değişimi mimarlık anlayışının da değişimine yol açmıştır. İnsanların mekânlarını kurgulama biçimleri değișen sosyo-ekonomik ve toplumsal koşullar ile birlikte değişim geçirmiştir. 20. yüzyllda küreselleşme eğilimi ile Modernizm'in getirdiği olanaklar, gelişen teknoloji ve dolayısıyla üretim biçimleri ile birlikte, 'yer'i esas almayan evrensel, standart, yerel verileri dişlayan rasyonalist mimari biçimler tasarlanmıştır. Modern dönemde zaman ve mekân kavramının yer bağlamından kopması, evrensel bir üslupla yerlerin artık her yer olması 'yersizleşmenin başlangıcı' olarak kabul edilir. Küreselleşme sonucu bölgesel sınırlar ortadan kalkmış, çevresel, doğal, kültürel, ulusal değerler yok olmaya başlamıştır. Dönemin bakış açısını Corbusier [3] şöyle özetler "...Tüm insanlar aynı organizmaya, aynı fonksiyon yapısina sahiptirler. Tüm insanlar aynı ihtiyaçlara sahiptirler..." Kendini tarihten soyutlayan modern mimarlığın rasyonalist ilkeleri, mimarlığın bütün coğrafyalar üzerinde benzer çözümler ve biçimler ile aynılaşarak 'yer'le ilişkisinin kopması, zamanla eleştirilmeye başlanmış ve modern karşıtı eleştiriler ortaya çıkmıştır. Modern mimarlığın evrensel tavrına karşı çıkan postmodernizm döneminde ise yerel olma kaygisıyla, görsel imgeler üzerinde yoğunlaşan 'yer'i bir temsil nesnesine indirgeyen 'yer' den kopuk mimari biçimler tasarlanmıştır [4]. Öyle ki modernler tarafından geleneksel mimarlığın kural ve sınırlamalarından kurtulmak için reddedilen tarihsel formlar, postmodernlerce modernist dogmadan kurtulmak ve kendi çoğulcu, özgür mimarlıklarını oluşturmak için kullanılmıştır [5]. Venturi'nin Mies'in 'less is more' deyiş̧ine gönderme yaptığı, “... Ben, nesnelerin "yalın" olanından çok kırma olanını, "başına buyruk" olanından çok uzlaşanını, "dosdoğru" olanını değil, çarpıtılmışını, "açıkça dile getirilenini" değil, anlamı belirsiz olanını, sapkın olduğu kadar kişilik dışı olanını, "ilginç" olduğu kadar can sıkıcı olanını severim" şeklindeki çıkışı mimarların yeni döneme bakışını da çok net ortaya koyuyordu [6]. Venturi, Mies van der Rohe'nin "az çoktur" sözünü eleştirerek tam karşıtı bir başkaldırışla "az, sıkıcıdır" demiştir. Harvey [7], bu durumu mekânsal engellerin çöküşü olarak nitelendirmiştir. Modernizme tepki olarak doğan postmodernizm de yer'le ilișkisini başarılı kuramamış yerel ve bölgesel mimari elemanlar bir dekor olarak kullanmıș, 'yer' yersizleşmiştir. Hâlbuki gerçek yerellik yer'in fiziksel koşullarını ve kültürel geçmişini göz önüne alarak tasarım yapmaktır. İşte bu noktada 'yersizleșmeye çözüm olarak' 1980'lerin söylemleştirdiği kavramsal çerçevesi ile tektipleşmelere karşı direnç noktaları ortaya koyan 'Eleștirel Bölgeselcilik (Critical Regionalism)' anlayıșı karşımıza çıkmaktadır. Eleştirel bölgeselci yaklaşım, topoğrafya, iklim, ışık gibi bölgesel nitelikleri, kültüre ilişkin verileri, mimarlığın tektonik ifadesi ile birleştirmiş, sahnesel olmayan, insanın algılayabildiği ve hissedebildiği, bulunduğu yere ait bir mimarlık önerisinde bulunur.

1940'lı ylllarda gelişmeye başlayan bölgeselcilik anlayışında, eleştirel bir bakış açısının şekillenmesine ön ayak olan kişi, Levis Mumford'dur. Levis Mumford, Skyline makalesinde, 1930'ların Uluslararası Stiline karşı modernizmin yerli ve insancıl biçimi olarak nitelediği "bölgesel stili" önermekte ve makine estetiğine yüklenmektedir [8]. Mumford'a göre evrensel-bölgesel ve mekanik-insana ait olan dengede tutulup sindirildikten sonra insanın istekleri, doğa, iklim, bitki örtüsü ve topoğrafya ile birliktelik sağlanmalıdır [9]. Eleştirel Bölgeselcilik kavramını ilk kez Lefaivre ve Tzonis 1981 deki "The Grid and The Pathway" adlı makalede ortaya koymuștur [10]. Lefaivre ve Tzonis, 'Eleștirel Bölgeselcilik' çerçevesinde değerlendirilebilecek bir binanın iki açıdan eleştirel olduğunu belirtir. Bunlardan birincisi, tasarımların ait olduğu bölgeselci geleneğin meşru olup olmadığı konusunda soru soruyor olmaları, ikincisi ise daha detaylı ele alınacak olan yabancılaștırma / yadırgatma'dır.

'Yabancılaştırma/yadırgatma' bölgeye ait olanı, yorumlayarak yeniden kullanmak olarak tanımlanırken, 'Eleştirel' olmanın koşullarından birini oluşturur [11]. Bu gelişmelerden sonra 'Eleştirel Rejyonalizm' kuramını en güçlü olanı teorisyen mimar Kenneth Frampton tarafından ortaya konulmuş; 1983 yılında altı, 1987 yılında on adet 
olmak üzere manifesto niteliğinde maddeler ortaya koymuş 'Eleștirel Rejyonalizm'in yaygınlaşmasını sağlamıştır. Frampton [12] makalelerinde mimarinin sadece moda ya da sahneleme gibi algllanıp tasarlanmasıyla ilgili endişelerini dile getirmiştir. Yerel kimlik ve ifadenin reddine karşı, yeri ve tektoniği anlayan gerçek mimari önermiştir. Yerin kültürü, topoğrafyası, bağlamı, iklimi, ışı̆̆ı ve tektonik formu binayı belirler [13]. Frampton [14]'a göre; bina serbest duran bir nesne olmayıp özellikle o yere uygun halde yapılmalıdır. Eleștirel bölgeselci yaklaşım, topoğrafya, iklim, ışık gibi bölgesel nitelikleri, kültüre ilișkin verileri, mimarlığın tektonik ifadesi ile birleştirmiş, sahnesel olmayan, insanın algılayabildiği ve hissedebildiği, bulunduğu yere ait bir mimarlık önerisinde bulunur.

Gelecek dönem mimarisinde "yer" ve "yerin ruhu" kavramlarının mimari tasarımdaki önemi daha çok hissedilecek dolayısıyla tasarlanacak mimari ürünlerde bu anlayışa uygun olacaktır varsayımından yola çıkarak çalışma, yerin ruhunu yaşatabilecek kriterlerin geliştirilmesine ihtiyaç olduğunu tespit etmiştir.

Yapılan literatür araştırması sonucunda "bir yapıyı eleștirel rejyonalist-o yer'e (bölgeye) ait olarak adlandırmak için, en çok hangi kriterler etkendir? Bu kriterlerin öncelik sıralaması nedir?" sorularına cevap veren bir çalışma olmadığı tespit edilmiştir. Bu çalışma; bu boşluğu doldurmak ve gelecek çalışmalara bir altlık olabilmek için bir adım olarak görülmüştür. Çalışmanın hedefi; "bir mimari ürünü eleştirel rejyonalist-o yer'e (bölgeye ait) olarak adlandırmak için gerekli evrensel tasarım kriterlerini belirlemek ve bu kriterlerin öncelik sıralamasını tespit etmektir". Bu amaçla yapılan literatür taramasına bağlı olarak yapılan değerlendirmeler sonucunda rejyonalizm konusunda en kapsamlı 'Eleștirel Bölgeselcilik' kuramının Kenneth Frampton'a ait olduğu görülmüş, 1987 yılında 'Bölgeselci Mimarlık için On Nokta: Geçici Bir Polemik' başlığı altında ortaya koyduğu maddeler yorumlanmış, bu yorumlardan anahtar kelimeler belirlenmiș ancak bu kriterlerin günümüzde yetersiz olduğu düşünülerek tarafımızdan yeni kriterler eklenerek bir yapıyı "eleştirel rejyonalist-o yer'e (bölgeye) ait" olarak adlandırmanın kriterleri, dört grup halinde ortaya konulmuştur. Ayrıca çalışma ortaya konulan tasarım kriterlerinin kavramsal düzeyde test edilmesine yönelik, uzmanlarla bir analiz çalışması yaparak, kriterlerin geçerliliklerini ve öncelik sırası tespit edilmiştir.

\section{Materyal ve Metot}

Araştırmanın amacına uygun veriler toplanırken literatür taraması, gözlem, görüşme ve anket veri toplama tekniklerinden yararlanılmıștır. Öncelikle kriterleri belirlemek için konu ile ilgili literatür taraması yapılmıştır. Yapılan literatür araştırması sonucu rejyonalizm konusunda en güncel ve kapsamlı olması nedeniyle Kenneth Frampton'ın 1987 yılında ortaya koyduğu on madde benimsenmiş, bu on madde analiz edilip anahtar kelimeler belirlenerek, bir yapıyı o yer'e ait olarak adlandırmanın "dokuz kriteri" ortaya konulmuştur ancak bu kriterlerin günümüz koşullarında yetersiz kaldığı düşüncesiyle "dört kriter" daha eklenerek toplam "on üç kriter", "bir mimari ürünü eleștirel rejyonalist-o yer'e (bölgeye) ait"olarak nitelendirmek için ortaya konulmuştur. Ayrıca kriterlerin geçerliliklerini ve öncelik sırasını tespit etmek amaçlı uzmanlarla anket çalışması yapılmıș, elde edilen anket sonuçları, karar analiz tekniklerinden AHP (Analytic Hierarchy Process) yöntemi ile değerlendirilmiștir.

\subsection{Yer'e özgü mimari tasarım kriterlerinin belirlenmesi}

Yapılan geniş kapsamlı literatür araştırmaları sonucunda eleştirel bölgesel konusunda en kapsamlı manifesto niteliğinde maddeler ortaya koyan araștırmacının Kenneth Frampton olduğu tespit edilmiştir. Frampton, bu madelerin ilkini 1983 yılında 'Mimari Direniş için Altı Nokta' (Towards a Critical Regionalism: Six Points For an Architecture of Resistance) başlığı altında toplamıștır. Frampton 1987 yılında, 1983 yılında ortaya koyduğu bu altı maddeden yola çıkarak 'Bölgeselci Mimarlık için On Nokta: Geçici Bir Polemik' başlığı altında maddelerini geliştirmiştir. Frampton'un 1983 yllında ortaya koyduğu altı nokta ve 1987 yılında ortaya koyduğu on noktada bir takım kavramlar tekrar ederken, diğer kavramlar eklenmiş veya eksiltilmiştir. Literatür taramasına bağlı olarak yapılan değerlendirmeler sonucunda geçmişten günümüze Eleştirel Bölgeselcilik ile ilgili en önemli kuramı 1987 yılında 'Bölgeselci Mimarlık için On Nokta: Geçici Bir Polemik' başlığı altında Kenneth Frampton'ın ortaya koyduğu belirlenmiştir (Tablo 1). Kriterler belirlenirken öncelikle bu on madde okunmuş ve yorumlanarak anahtar kelimeler (kriterler) belirlenmiştir.

Tablo 1. Ten points on an Architecture of Regionalism: A Provisional Polemic

1.Critical Regionalism And Vernacular Form

2.The Modern Movement
3.The Myth and the Reality of the Region
4. Information and Experience
5.Space/Place
6.Typology/Topography
7.Architectonic/Scenographic
8.Artificial/Natural
9.Visual/Tactile
10.Post-Modernism and Regionalism: A Summation

Çalışma kapsamında Frampton'ın bu on maddesi yorumlanarak analiz edildiğinde bir yapıyı eleştirel bölgesel olarak adlandırmada yer'e ait olmanın 
göstergesi olarak "topografyaya uyum", "doğaya saygı", "doğal aydınlatmanın kullanımı", "iklim verilerinin dikkate alma", "yapının rengi ve dokusuyla birlikte çevre dokuyla uyumlu olması", "yerel malzemenin kullanımı", "dokunsal olma" "yerel yapım tekniğinin kullanımı", "yerel mimari elemanların kullanımı" kavramlarına ișaret ettiği görülmüștür. Ancak yerel elemanların basit duygusallıkla bağlanılan vernaküler șeklinde değil yorumlanarak kullanılması gerektiğine vurgu yapmaktadır. Yukarıda belirlenen anahtar kelimeler çalıșma kapsamında bir mimari ürünü 'eleştirel rejyonalist-o yer'e (bölgeye) ait' olarak adlandırmanın dokuz kriteri olarak belirlenmiștir. Ancak bu kriterlerin bir yapıyı eleștirel bölgesel olarak tek başına adlandırma da yetersiz olduğu düșünülmüștür. Bölgesel yapılar incelendiğinde, "fonksiyonunu dişa yansıttıkları", "sade biçim diline sahip oldukları", "insan ölçeğine yakın oldukları" ve "çevre yapılarla ölçekli oldukları" tespit edilip, daha önce belirlenen dokuz kritere, tarafimızdan dört kriter daha eklenip toplam on üç adet evrensel kriter, bir mimari ürünü "eleștirel rejyonalist" olarak adlandırmanın güncel kriterleri olarak belirlenmiştir (Tablo 2).

Tablo 2. Bir mimari ürünü 'eleştirel rejyonalist-o yer'e (bölgeye) ait' olarak adlandırmanın tasarım kriterleri

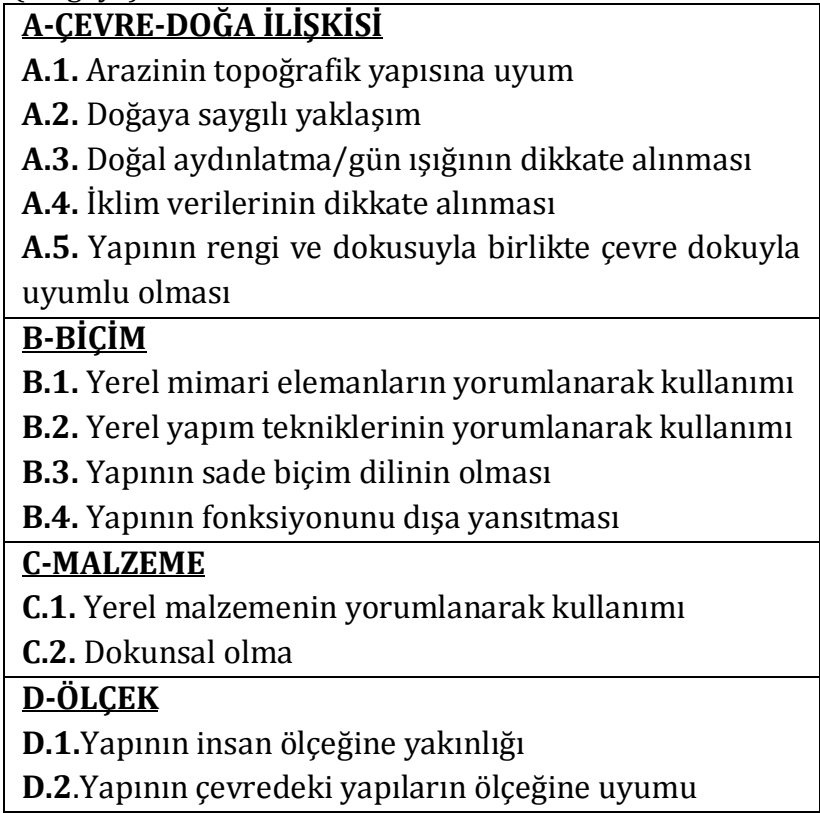

\subsection{Anket tekniği ile uzmanlardan veri toplanması}

Çalışma kapsamında ortaya konulan kriterlerin kavramsal düzeyde geçerliliğini ve öncelik sırasını belirlemek için uzmanlarla bir anket çalışması yapılmıștır. "Bir yapıyı eleștirel rejyonalist-o yer'e (bölgeye) ait" olarak nitelendirmek için belirlenen 13 kriterin içerisinde yer aldığı bir anket formu hazırlanmış ve uzmanlardan bu kriterleri önem sırasına göre puanlamaları istenmiștir. Çalıșmanın örneklemi seçilirken, çalışmanın iç dinamikleri etkili olmuş, kriterler arasında doğru sıralamayı ancak "rejyonalizm" konusunda uzmanlar yapabileceği için doktor unvanına sahip anket konusunda uzman, Gazi Üniversitesi, ODTÜ ve Selçuk Üniversitesi bina bilgisi, restorasyon ve mimarlık tarihi kürsüsünde yer alan mimari tasarım stüdyosu dersi yürüten 34 uzman mimar seçilmiștir. Örneklem için gerekli örneklem büyüklüğü hesaplandığında (Tablo 3);

Yığın ortalaması için $\bar{x}$ ve s sırasıyla örnek ortalaması ve örnek standart sapması olmak üzere $1-\alpha$ anlamlılık ve d duyarlılık düzeyinde güven aralığı Denklem 1' deki gibi ifade edilir.

$$
P\left(\bar{x}-t_{n-1, \alpha / 2} \frac{s}{\sqrt{n}}<\mu<\bar{x}-t_{n-1, \alpha / 2} \frac{s}{\sqrt{n}}\right)=P\left(\bar{x} \pm t_{n-1,1-\alpha / 2} \frac{s}{\sqrt{n}}\right)=P(\bar{x} \pm d)=1-\alpha(1)
$$

10 akademisyen ile pilot çalışma uygulaması yapılmış aşağıdaki bulgular ve talepler doğrultusunda örnek hacmi hesaplanmiştır. 13 soruya (kriterlere) verilen cevaplar değerlendirilmiş ve bunlar arasında en yüksek standart sapma örnek hacminin belirlenmesinde kullanılmıştır (Tablo 4).

$$
\begin{aligned}
& d=t_{n-1,1-\alpha / 2} \frac{s}{\sqrt{n}} \\
& 1=t_{10-1,1-0,05 / 2} \frac{2,58}{\sqrt{n}}=t_{9,0,975} \frac{2,58}{\sqrt{n}} \\
& \sqrt{n}=t_{9,0,975} 2,58=2,262 * 2,58=5,83 \\
& n=34,058 \cong 34 \text { olarak belirlenmiştir. }
\end{aligned}
$$

$\mathrm{Bu}$ amaçla hazırlanan A4 basılı anket soru formları, çalışma kapsamında literatür araştırmaları, gözlem ve görüşme teknikleri neticesinde belirlenen 13 adet kriterin gruplandırılarak (ölçek, malzeme, çevredoğa, biçim) öncelik seviyesinin sorulması șeklinde oluşturulmuştur. Anket formu, çalışmanın kapsamında belirlenen "bir yapının eleștirel rejyonalist-o yer'e (bölgeye) ait” olarak nitelenmesinde etken olduğu düşünülen on üç kriterin her birinin önem derecesine göre, uzmanlar tarafından 1-10 aralığında (HİÇ önemli değil / ÇOK önemli) değerlendirmesini sağlayacak şekilde tasarlanmıştır.

Hazırlanan anketler, uzmanlarla yüz yüze 1 ay içerisinde tamamlanmıştır. Örneklem için gerekli örneklem büyüklügü hesaplanmış, 34 adet uzman mimarla anket yapılmıştır. Toplam 34 akademisyene uygulanan anket sonuçlarının 2 tanesinde eksik cevaplamalar olması nedeni ile 32 anket, analize uygun bulunmuş ve değerlendirilmiștir. Anket uygulaması sonucu elde edilen veriler, bilgisayar ortamına uygun hale getirilmiştir. 
Tablo 3. İlkelere pilot çalışmada verilen cevapların istatistikleri

\begin{tabular}{|c|c|c|c|c|c|c|}
\hline & $\mathbf{N}$ & Minimum & Maximum & Ortalama & $\begin{array}{l}\text { Standart } \\
\text { Sapma }\end{array}$ & Varyans \\
\hline Yapının arazinin topoğrafik yapısına uygun konumlanması & 10 & 8,00 & 10,00 & 9,4000 & 69921 & 489 \\
\hline $\begin{array}{l}\text { Yapının doğaya saygılı ve bütüncül bir yaklaşımla } \\
\text { tasarlanması (Yapının toprağa, su kaynaklarına, Flora, } \\
\text { Faunaya, çevresel sistemlere saygılı olması) }\end{array}$ & 10 & 6,00 & 10,00 & 8,8000 & 1,47573 & 2,178 \\
\hline $\begin{array}{l}\text { Yapı tasarlanırken doğal aydınlatma/gün ıșığının dikkate } \\
\text { alınması(Yapıdaki pencereler, doluluklar, boşluklar dikkate } \\
\text { alındığında yapının doğal aydınlatma düşünülerek } \\
\text { tasarlanması) }\end{array}$ & 10 & 6,00 & 10,00 & 7,7000 & 1,25167 & 1,567 \\
\hline $\begin{array}{l}\text { Yapı tasarlanırken iklim verilerinin dikkate alınması } \\
\text { (Yapının güneş ışığı, doğal ısıtma, doğal havalandırma, doğal } \\
\text { gölgelendirme düşünülerek tasarlanması) }\end{array}$ & 10 & 6,00 & 10,00 & 8,0000 & 1,33333 & 1,778 \\
\hline $\begin{array}{l}\text { Yapının rengi ve dokusuyla birlikte çevre doku ile uyumlu } \\
\text { olması (Yapı çevre ilişkisi açısından yapının ait olduğu } \\
\text { çevredeki yapıların malzemesi ve rengiyle bütünleşik bir } \\
\text { șekilde tasarlanması, tek başına ayrık durmaması) }\end{array}$ & 10 & 3,00 & 9,00 & 7,5000 & 1,95789 & 3,833 \\
\hline $\begin{array}{l}\text { Yapıda yerel mimari elemanların (kemer, kolon, saçak } \\
\text { uzunluğu pencere/kapı sövesi, çatı eğimi vs.) yorumlanarak } \\
\text { kullanımı }\end{array}$ & 10 & 5,00 & 10,00 & 7,9000 & 1,91195 & 3,656 \\
\hline $\begin{array}{l}\text { Yapıda yerel yapım tekniklerinin (yığma, ahşap kalıp } \\
\text { sistemi vs.) yorumlanarak kullanımı }\end{array}$ & 10 & 2,00 & 10,00 & 6,3000 & 2,58414 & 6,678 \\
\hline $\begin{array}{l}\text { Yapının sade bir biçim diline sahip olması (yapının tasarım } \\
\text { anlayıșının yalın ve anlașılabilir olması) }\end{array}$ & 10 & 5,00 & 10,00 & 7,4000 & 1,77639 & 3,156 \\
\hline $\begin{array}{l}\text { Yapının fonksiyonunu dıșa yansıtabilmesi (yapının } \\
\text { fonksiyonunun dışarıdan izleyen tarafından net bir șekilde } \\
\text { algılanabilmesi) }\end{array}$ & 10 & 5,00 & 8,00 & 6,8000 & 1,22927 & 1,511 \\
\hline $\begin{array}{l}\text { Yapıda yerel malzemenin (Fiziki çevrede bulunan taş, } \\
\text { toprak, ahşap, kerpiç vs yerel malzemeler...) yorumlanarak } \\
\text { kullanımı }\end{array}$ & 10 & 4,00 & 10,00 & 7,6000 & 2,17051 & 4,711 \\
\hline $\begin{array}{l}\text { Yapıda kullanılan malzemeler dikkate alındığında } \\
\text { dokunsallığın hissedilmesi (sadece görsel duyulara değil, } \\
\text { aynı zamanda koku, ses, ısı gibi farklı alglara hitap edebilen } \\
\text { malzeme kullanımı) }\end{array}$ & 10 & 5,00 & 9,00 & 6,8000 & 1,39841 & 1,956 \\
\hline $\begin{array}{l}\text { Yapı kütlesinin insan ölçeğine yakınlığı (Ölçüler oranlar } \\
\text { dikkate alındığında yapının insanı ezmeyen, insancıl bir } \\
\text { tavrının olması) }\end{array}$ & 10 & 4,00 & 10,00 & 8,4000 & 1,95505 & 3,822 \\
\hline $\begin{array}{l}\text { Yapı kütlesinin çevredeki yapıların ölçeğine uyumu } \\
\text { (Yapını ait olduğu çevredeki mevcut yapılar ile orantılı ve } \\
\text { ölçekli olması) }\end{array}$ & 10 & 5,00 & 10,00 & 8,3000 & 1,49443 & 2,233 \\
\hline
\end{tabular}

Tablo 4. Örnekleme hacmi için kullanılan parametre ve değerleri

\begin{tabular}{|l|l|}
\hline 7. kriterin örnek standart sapması $(s)$ & 2,58 \\
\hline Güven aralığı düzeyi $(1-\alpha)$ & 0,95 \\
\hline Duyarlılık $(d)$ & 1,00 \\
\hline I. tip hata $(\alpha)$ & 0,05 \\
\hline Pilot çalışmanın hacmi & 10 \\
\hline$t_{9,0,975}$ & 2,262 \\
\hline
\end{tabular}

2.3. AHP yöntemiyle kriterlerinin öncelikli ağırlık değerlerinin belirlenmesi ve önem sıralamasının yapılması

Anket uygulaması sonucu elde edilen veriler, bilgisayar ortamına uygun hale getirilmiş, anket verileri karar analiz tekniklerinden AHP (Analytic Hierarchy Process) yöntemi ile değerlendirilmiştir. $\mathrm{Bu}$ çalışmada AHP yöntemi, çalışma kapsamında ortaya konulan 'bir yapıyı eleştirel rejyonalist-o yer'e (bölgeye) ait olarak tanımlayan kriterlerin birbirilerine göre önem ağırlıkları' tespit ederek 'bir yapının eleștirel rejyonalist-o yer'e (bölgeye) ait olarak nitelenmesinde göreli önem ă̆ırlığı en yüksek olan kriterin tespiti' amaciyla kullanılmaktadır. Şekil 1'de görüldüğü gibi 4 kriter grubu ve bu kriter gruplarının farklı sayıda kriterleri vardır. Uzmanlar ankette bu ölçütleri 1-10 skalasında değerlendirmişlerdir.

Anket sonuçları örneklem olarak seçilen 32 uzmanın değerlendirmesi baz alınarak hesaplanmıştır. Çıkan sonuçların birbirine oranlaması sonucunda en az 1, en çok 10 arasında değerler bulunmuştur. Çıkan oransal değerlere karşılık AHP'nin 1-9 temel ölçeğine göre yapılan aralıklandırmalar sonucunda değerler verilmiş ve ikili karşılaştırmalarda bu değerler kullanılmıştır. Uzmanların verdiği önem puanlarının toplanması sonucu A-1 kriteri 297 puan ile en önemli ve C-2 kriteri ise 156 puan ile en önemsiz kriter olarak belirlenmiştir. Kriter grubu olarak 270,4 ortalama puan ile A kriter grubu en önemli ve 185,5 puan ile $\mathrm{C}$ kriter grubu ise en önemsiz kriter grubu olarak belirlenmiștir. 


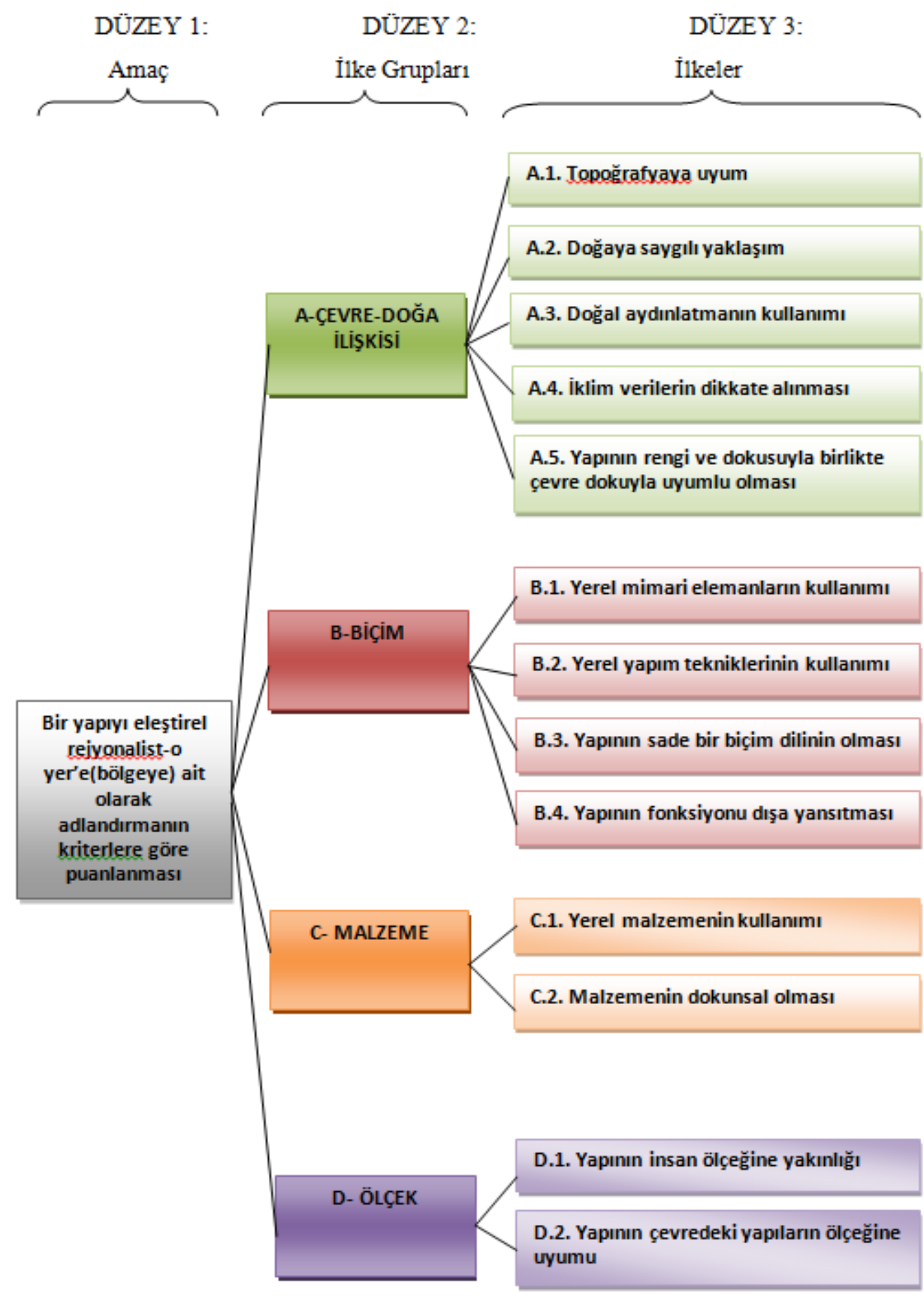

Şekil 1. Değerlendirme kriterlerine ait oluşturulan hiyerarşik organizasyon şeması

Ancak bu değerlendirmeler karşılaştırmalı değerlendirmeler değildir. Bu sebeple, ölçütler arasındaki değerlendirmeleri yapılabilmesi için oransal değerlerin belirlenmesi ve analizi gerekmektedir.

Oransal değerlerin verilerden toplanarak belirlenmesi ve AHP önem derecelerinin belirlenmesinden sonra AHP analizi ile karşılaştırmalı (hiyerarşik) değerlendirmeler belirlenmiștir.

- Ölçütler Arasında Önem Sıralarının Belirlenmesi ve AHP önem dereceleri
Oranlama için aşağıdaki değerler incelenebilir.

A- $1 / C-2=297 / 156=1.903$

Bunun anlamı; A-1 kriterine verilen puanların toplamı, C-2 kriterine verilen puanların toplamının 1.903 katıdır. 1,903 oranı Tablo 5'de yapılan AHP önem derecelendirmesinde 2 değerini almaktadır. $\mathrm{Bu}$ nedenle, A-1 kriteri, C-2 kriterine göre 2 kat önemlidir denir. Diğer karşılaştırmalarda da oranlamaya göre aralık değerleri verilmiş ve ikili karşılaştırmalar aynı mantık çerçevesinde yapılmıştır. 
Tablo 5. 1-10 temel ölçeğine göre yapılan AHP derecelendirmesi $[15,16]$

\begin{tabular}{|c|c|c|c|}
\hline $\begin{array}{c}\text { Gerçek } \\
\text { Oran }\end{array}$ & $\begin{array}{c}\text { Önem } \\
\text { Derecesi }\end{array}$ & Tanım & Açıklama \\
\hline $\begin{array}{c}1,000- \\
1,111\end{array}$ & 1 & $\begin{array}{c}\text { Eşit } \\
\text { derecede } \\
\text { önemli } \\
\end{array}$ & $\begin{array}{l}\text { İki faktör aynı } \\
\text { derecede önem } \\
\text { taşımaktadır. }\end{array}$ \\
\hline $\begin{array}{c}1,112- \\
2,222\end{array}$ & 2 & $\begin{array}{c}\text { Ara } \\
\text { değer }\end{array}$ & $\begin{array}{c}\text { Uzlaşma } \\
\text { gerektiğinde } \\
\text { kullanılmak üzere } \\
\text { iki ardışık yargl } \\
\text { arasındaki değerler. }\end{array}$ \\
\hline $\begin{array}{c}2,223- \\
3,333\end{array}$ & 3 & $\begin{array}{c}\text { Orta } \\
\text { derecede } \\
\text { önemli }\end{array}$ & $\begin{array}{l}\text { İki faktörden biri } \\
\text { diğerine göre biraz } \\
\text { daha önem } \\
\text { taşımaktadır. }\end{array}$ \\
\hline $\begin{array}{c}3,334- \\
4,444\end{array}$ & 4 & $\begin{array}{c}\text { Ara } \\
\text { değer }\end{array}$ & $\begin{array}{c}\text { Uzlașma } \\
\text { gerektiğinde } \\
\text { kullanılmak üzere } \\
\text { iki ardışık yargı } \\
\text { arasındaki değerler. }\end{array}$ \\
\hline $\begin{array}{c}4,445- \\
5,555\end{array}$ & 5 & $\begin{array}{c}\text { Kuvvetli } \\
\text { derecede } \\
\text { önemli }\end{array}$ & $\begin{array}{l}\text { İki faktörden biri } \\
\text { diğerine göre fazla } \\
\text { önem tașımaktadır. }\end{array}$ \\
\hline $\begin{array}{c}5,556- \\
6,666\end{array}$ & 6 & $\begin{array}{c}\text { Ara } \\
\text { değer }\end{array}$ & $\begin{array}{c}\text { Uzlaşma } \\
\text { gerektiğinde } \\
\text { kullanılmak üzere } \\
\text { iki ardışık yargl } \\
\text { arasındaki değerler. }\end{array}$ \\
\hline $\begin{array}{c}6,667- \\
7,777\end{array}$ & 7 & $\begin{array}{c}\text { Çok } \\
\text { kuvvetli } \\
\text { derecede } \\
\text { önemli }\end{array}$ & $\begin{array}{l}\text { İki faktörden biri } \\
\text { diğerine göre çok } \\
\text { fazla önem } \\
\text { tașımaktadır. }\end{array}$ \\
\hline $\begin{array}{c}7,778- \\
8,888\end{array}$ & 8 & $\begin{array}{c}\text { Ara } \\
\text { değer }\end{array}$ & $\begin{array}{c}\text { Uzlaşma } \\
\text { gerektiğinde } \\
\text { kullanılmak üzere } \\
\text { iki ardışık yargl } \\
\text { arasındaki değerler. }\end{array}$ \\
\hline $\begin{array}{l}8,889- \\
10.000\end{array}$ & 9 & $\begin{array}{l}\text { Kesin } \\
\text { önemli }\end{array}$ & $\begin{array}{l}\text { İki faktörden biri } \\
\text { diğerine göre aşırı } \\
\text { derecede önem } \\
\text { taşımaktadır. }\end{array}$ \\
\hline
\end{tabular}

AHP'nin ikinci adımda; uzmanların, tüm kriterlerin birbiri üzerindeki önem derecelerinin belirlenmesi için ikili karşılaştırma matrislerinin oluşturulmasına dayanır. İlk olarak 'amaca' göre kriterler ikili olarak karşılaștırılır. On üç kriterin amaca göre ikili karşılaștırma yarglarının matris halinde düzenlenmiş şekli ise Denklem 2'deki gibidir.

$$
\left[\begin{array}{ccccccccccccc}
1 & 1 & 2 & 1 & 2 & 2 & 2 & 2 & 2 & 2 & 2 & 2 & 2 \\
1 & 1 & 1 & 1 & 2 & 2 & 2 & 2 & 2 & 2 & 2 & 2 & 1 \\
0,5 & 1 & 1 & 0,5 & 1 & 2 & 2 & 2 & 2 & 2 & 2 & 1 & 1 \\
1 & 1 & 1 & 1 & 2 & 2 & 2 & 2 & 2 & 2 & 2 & 1 & 1 \\
0,5 & 0,5 & 0,5 & 0,5 & 1 & 2 & 2 & 2 & 2 & 2 & 2 & 1 & 1 \\
0,5 & 0,5 & 0,5 & 0,5 & 0,5 & 1 & 2 & 1 & 2 & 1 & 2 & 0,5 & 0,5 \\
0,5 & 0,5 & 0,5 & 0,5 & 0,5 & 0,5 & 1 & 1 & 1 & 0,5 & 1 & 0,5 & 0,5 \\
0,5 & 0,5 & 0,5 & 0,5 & 0,5 & 1 & 1 & 1 & 1 & 0,5 & 2 & 0,5 & 0,5 \\
0,5 & 0,5 & 0,5 & 0,5 & 0,5 & 0,5 & 1 & 1 & 1 & 0,5 & 1 & 0,5 & 0,5 \\
0,5 & 0,5 & 0,5 & 0,5 & 0,5 & 1 & 2 & 2 & 2 & 1 & 2 & 0,5 & 0,5 \\
0,5 & 0,5 & 0,5 & 0,5 & 0,5 & 0,5 & 1 & 0,5 & 1 & 0,5 & 1 & 0,5 & 0,5 \\
0,5 & 0,5 & 1 & 1 & 1 & 2 & 2 & 2 & 2 & 2 & 2 & 1 & 1 \\
0,5 & 1 & 1 & 1 & 1 & 2 & 2 & 2 & 2 & 2 & 2 & 1 & 1
\end{array}\right]
$$

Ardından olușturulan ikili matrisler, 'normalize edilmiș ağırlık vektörünün hesaplanması' ve 'satır ortalaması' şeklindeki işlem ve hesaplamalara tabi tutularak, amaç için 'göreli önemleri' belirlenmiştir Öncelikle A matrisindeki 13 adet sütunun toplamı bulunmuş, sütun toplamlarına göre normalizasyonu hesaplanmış ve elde elden sonucun satır ortalaması değeri bulunarak kriterlerin göreli önem ağırlığ hesaplanmıştır. Denklem 3'den Denklem 6'e kadar sırasıyla verilmiştir.

\section{$A$ matrisinin 13 adet sütun toplamı}

$A_{T}=\left[\begin{array}{lllllllllllll}a_{t 1} & a_{t 2} & a_{t 3} & a_{t 4} & a_{t 5} & a_{t 6} & a_{t 7} & a_{t 8} & a_{t 9} & a_{t 10} & a_{t 11} & a_{t 12} & a_{t 13}\end{array}\right]$

burada $a_{t i}=\sum_{j=1}^{13} a_{j i}, i=1, . ., 13$ ve $j=1, . ., 13$

$$
\begin{aligned}
a_{t 1} & =\sum_{j=1}^{13} a_{j 1}=a_{11}+a_{21}+a_{31}+a_{41}+a_{51}+a_{61}+a_{71}+a_{81}+a_{91}+a_{101}+a_{111}+a_{121}+a_{131} \\
& =1+1+0,5+1+0,5+0,5+0,5+0,5+0,5+0,5+0,5+0,5+0,5=8,0
\end{aligned}
$$

$$
\begin{aligned}
a_{t 2} & =\sum_{j=1}^{13} a_{j 2}=a_{12}+a_{22}+a_{32}+a_{42}+a_{52}+a_{62}+a_{72}+a_{82}+a_{92}+a_{102}+a_{112}+a_{122}+a_{132} \\
& =1+1+1+1+0,5+0,5+0,5+0,5+0,5+0,5+0,5+0,5+1=9,0
\end{aligned}
$$$$
a_{t 3}=\sum_{j=1}^{13} a_{j 3}=a_{13}+a_{23}+a_{33}+a_{43}+a_{53}+a_{63}+a_{73}+a_{83}+a_{93}+a_{103}+a_{113}+a_{123}+a_{133}
$$ 


$$
=2+1+1+1+0,5+0,5+0,5+0,5+0,5+0,5+0,5+1+1=10,5
$$

$$
\begin{aligned}
a_{t 4} & =\sum_{j=1}^{13} a_{j 4}=a_{14}+a_{24}+a_{34}+a_{44}+a_{54}+a_{64}+a_{74}+a_{84}+a_{94}+a_{104}+a_{114}+a_{124}+a_{134} \\
& =1+1+0,5+1+0,5+0,5+0,5+0,5+0,5+0,5+0,5+1+1=9,0 \\
a_{t 5} & =\sum_{j=1}^{13} a_{j 5}=a_{15}+a_{25}+a_{35}+a_{45}+a_{55}+a_{65}+a_{75}+a_{85}+a_{95}+a_{105}+a_{115}+a_{125}+a_{135} \\
& =2+2+1+2+1+0,5+0,5+0,5+0,5+0,5+0,5+1+1=13,0
\end{aligned}
$$

$$
\begin{aligned}
a_{t 6} & =\sum_{j=1}^{13} a_{j 6}=a_{16}+a_{26}+a_{36}+a_{46}+a_{56}+a_{66}+a_{76}+a_{86}+a_{96}+a_{106}+a_{116}+a_{126}+a_{136} \\
& =2+2+2+2+2+1+0,5+1+0,5+1+0,5+2+2=18,5
\end{aligned}
$$

$$
\begin{aligned}
a_{t 7} & =\sum_{j=1}^{13} a_{j 7}=a_{17}+a_{27}+a_{37}+a_{47}+a_{57}+a_{67}+a_{77}+a_{87}+a_{97}+a_{107}+a_{117}+a_{127}+a_{137} \\
& =2+2+2+2+2+2+1+1+1+2+1+2+2=22,0
\end{aligned}
$$

$$
\begin{aligned}
a_{t 8} & =\sum_{j=1}^{13} a_{j 8}=a_{18}+a_{28}+a_{38}+a_{48}+a_{58}+a_{68}+a_{78}+a_{88}+a_{98}+a_{108}+a_{118}+a_{128}+a_{138} \\
& =2+2+2+2+2+1+1+1+1+2+0,5+2+2=20,5
\end{aligned}
$$

$$
\begin{aligned}
a_{t 9} & =\sum_{j=1}^{13} a_{j 9}=a_{19}+a_{29}+a_{39}+a_{49}+a_{59}+a_{69}+a_{79}+a_{89}+a_{99}+a_{109}+a_{119}+a_{129}+a_{139} \\
& =2+2+2+2+2+2+1+1+1+2+1+2+2=22,0
\end{aligned}
$$

$$
\begin{aligned}
a_{t 10} & =\sum_{j=1}^{13} a_{j 10}=a_{110}+a_{210}+a_{310}+a_{410}+a_{510}+a_{610}+a_{710}+a_{810}+a_{910}+a_{1010}+a_{1110}+a_{1210}+a_{1310} \\
& =2+2+2+2+2+1+0,5+0,5+0,5+1+0,5+2+2=18,0
\end{aligned}
$$

$$
\begin{aligned}
a_{t 11} & =\sum_{j=1}^{13} a_{j 11}=a_{111}+a_{211}+a_{311}+a_{411}+a_{511}+a_{611}+a_{711}+a_{811}+a_{911}+a_{1011}+a_{1111}+a_{1211}+a_{1311} \\
& =2+2+2+2+2+2+1+2+1+2+1+2+2=23,0
\end{aligned}
$$

$$
\begin{aligned}
a_{t 12} & =\sum_{j=1}^{13} a_{j 12}=a_{112}+a_{212}+a_{312}+a_{412}+a_{512}+a_{612}+a_{712}+a_{812}+a_{912}+a_{1012}+a_{1112}+a_{1212}+a_{1312} \\
& =2+2+1+1+1+0,5+0,5+0,5+0,5+0,5+0,5+1+1=12,0
\end{aligned}
$$

$$
\begin{aligned}
a_{t 13} & =\sum_{j=1}^{13} a_{j 13}=a_{113}+a_{213}+a_{313}+a_{413}+a_{513}+a_{613}+a_{713}+a_{813}+a_{913}+a_{1013}+a_{1113}+a_{1213}+a_{1313} \\
& =2+1+1+1+1+0,5+0,5+0,5+0,5+0,5+0,5+1+1=11,0 \text { olmak üzere }
\end{aligned}
$$

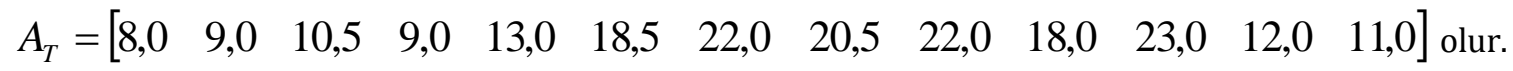




\section{$A$ matrisinin sütun toplamlarına göre normalizasyonu}

$$
A_{W}=\left[\begin{array}{ccccccccccccc}
\frac{1}{8} & \frac{1}{9} & \frac{2}{10,5} & \frac{1}{9} & \frac{2}{13} & \frac{2}{18,5} & \frac{2}{22} & \frac{2}{20,5} & \frac{2}{22} & \frac{2}{18} & \frac{2}{23} & \frac{2}{12} & \frac{2}{11} \\
\frac{1}{8} & \frac{1}{9} & \frac{1}{10,5} & \frac{1}{9} & \frac{2}{13} & \frac{2}{18,5} & \frac{2}{22} & \frac{2}{20,5} & \frac{2}{22} & \frac{2}{18} & \frac{2}{23} & \frac{2}{12} & \frac{1}{11} \\
\frac{0,5}{8} & \frac{1}{9} & \frac{1}{10,5} & \frac{0,5}{9} & \frac{1}{13} & \frac{2}{18,5} & \frac{2}{22} & \frac{2}{20,5} & \frac{2}{22} & \frac{2}{18} & \frac{2}{23} & \frac{1}{12} & \frac{1}{11} \\
\frac{1}{8} & \frac{1}{9} & \frac{1}{10,5} & \frac{1}{9} & \frac{2}{13} & \frac{2}{18,5} & \frac{2}{22} & \frac{2}{20,5} & \frac{2}{22} & \frac{2}{18} & \frac{2}{23} & \frac{1}{12} & \frac{1}{11} \\
\frac{0,5}{8} & \frac{0,5}{9} & \frac{0,5}{10,5} & \frac{0,5}{9} & \frac{1}{13} & \frac{2}{18,5} & \frac{2}{22} & \frac{2}{20,5} & \frac{2}{22} & \frac{2}{18} & \frac{2}{23} & \frac{1}{12} & \frac{1}{11} \\
\frac{0,5}{8} & \frac{0,5}{9} & \frac{0,5}{10,5} & \frac{0,5}{9} & \frac{0,5}{13} & \frac{1}{18,5} & \frac{2}{22} & \frac{1}{20,5} & \frac{2}{22} & \frac{1}{18} & \frac{2}{23} & \frac{0,5}{12} & \frac{0,5}{11} \\
\frac{0,5}{8} & \frac{0,5}{9} & \frac{0,5}{10,5} & \frac{0,5}{9} & \frac{0,5}{13} & \frac{0,5}{18,5} & \frac{1}{22} & \frac{1}{20,5} & \frac{1}{22} & \frac{0,5}{18} & \frac{1}{23} & \frac{0,5}{12} & \frac{0,5}{11} \\
\frac{0,5}{8} & \frac{0,5}{9} & \frac{0,5}{10,5} & \frac{0,5}{9} & \frac{0,5}{13} & \frac{1}{18,5} & \frac{1}{22} & \frac{1}{20,5} & \frac{1}{22} & \frac{0,5}{18} & \frac{2}{23} & \frac{05}{12} & \frac{0,5}{11} \\
\frac{0,5}{8} & \frac{0,5}{9} & \frac{0,5}{10,5} & \frac{0,5}{9} & \frac{0,5}{13} & \frac{0,5}{18,5} & \frac{1}{22} & \frac{1}{20,5} & \frac{1}{22} & \frac{0,5}{18} & \frac{1}{23} & \frac{0,5}{12} & \frac{0,5}{11} \\
\frac{0,5}{8} & \frac{0,5}{9} & \frac{0,5}{10,5} & \frac{0,5}{9} & \frac{0,5}{13} & \frac{1}{18,5} & \frac{2}{22} & \frac{2}{20,5} & \frac{2}{22} & \frac{1}{18} & \frac{2}{23} & \frac{0,5}{12} & \frac{0,5}{11} \\
\frac{0,5}{8} & \frac{0,5}{9} & \frac{0,5}{10,5} & \frac{0,5}{9} & \frac{0,5}{13} & \frac{0,5}{18,5} & \frac{1}{22} & \frac{0,5}{20,5} & \frac{1}{22} & \frac{0,5}{18} & \frac{1}{23} & \frac{0,5}{12} & \frac{0,5}{11} \\
\frac{0,5}{8} & \frac{0,5}{9} & \frac{1}{10,5} & \frac{1}{9} & \frac{1}{13} & \frac{2}{18,5} & \frac{2}{22} & \frac{2}{20,5} & \frac{2}{22} & \frac{2}{18} & \frac{2}{23} & \frac{1}{12} & \frac{1}{11} \\
\frac{0,5}{8} & \frac{1}{9} & \frac{1}{10,5} & \frac{1}{9} & \frac{1}{13} & \frac{2}{18,5} & \frac{2}{22} & \frac{2}{20,5} & \frac{2}{22} & \frac{2}{18} & \frac{2}{23} & \frac{1}{12} & \frac{1}{11}
\end{array}\right]
$$

\section{Normalize edilmiş ağırlık vektörleri}

$A_{W}=\left[\begin{array}{lllllllllllll}0,125 & 0,111 & 0,190 & 0,111 & 0,154 & 0,108 & 0,091 & 0,098 & 0,091 & 0,111 & 0,087 & 0,167 & 0,182 \\ 0,125 & 0,111 & 0,095 & 0,111 & 0154 & 0,108 & 0,091 & 0,098 & 0,091 & 0,111 & 0,087 & 0,167 & 0,091 \\ 0,063 & 0,111 & 0,095 & 0,056 & 0,077 & 0,108 & 0,091 & 0,098 & 0,091 & 0,111 & 0,087 & 0,083 & 0,091 \\ 0,125 & 0,111 & 0,095 & 0,111 & 0,154 & 0,108 & 0,091 & 0,098 & 0,091 & 0,111 & 0,087 & 0,083 & 0,091 \\ 0,063 & 0,056 & 0,048 & 0,056 & 0,077 & 0,108 & 0,091 & 0,098 & 0,091 & 0,111 & 0,087 & 0,083 & 0,091 \\ 0,063 & 0,056 & 0,048 & 0,056 & 0,038 & 0,054 & 0,091 & 0,049 & 0,091 & 0,056 & 0,087 & 0,042 & 0,045 \\ 0,063 & 0,056 & 0,048 & 0,056 & 0,038 & 0,027 & 0,045 & 0,049 & 0,045 & 0,028 & 0,043 & 0,042 & 0,045 \\ 0,063 & 0,056 & 0,048 & 0,056 & 0,038 & 0,054 & 0,045 & 0,049 & 0,045 & 0,028 & 0,087 & 0,042 & 0,045 \\ 0,063 & 0,056 & 0,048 & 0,056 & 0,038 & 0,027 & 0,045 & 0,049 & 0,045 & 0,028 & 0,043 & 0,042 & 0,045 \\ 0,063 & 0,056 & 0,048 & 0,056 & 0,038 & 0,054 & 0,091 & 0,098 & 0,091 & 0,056 & 0,087 & 0,042 & 0,045 \\ 0,063 & 0,056 & 0,048 & 0,056 & 0,038 & 0,027 & 0,045 & 0,024 & 0,045 & 0,028 & 0,043 & 0,042 & 0,045 \\ 0,063 & 0,056 & 0,095 & 0,111 & 0,077 & 0,108 & 0,091 & 0,098 & 0,091 & 0,111 & 0,087 & 0,083 & 0,091 \\ 0,063 & 0,111 & 0,095 & 0,111 & 0,077 & 0,108 & 0,091 & 0,098 & 0,091 & 0,111 & 0,087 & 0,083 & 0,091\end{array}\right]$

\section{$W$ göreli önem vektörü}
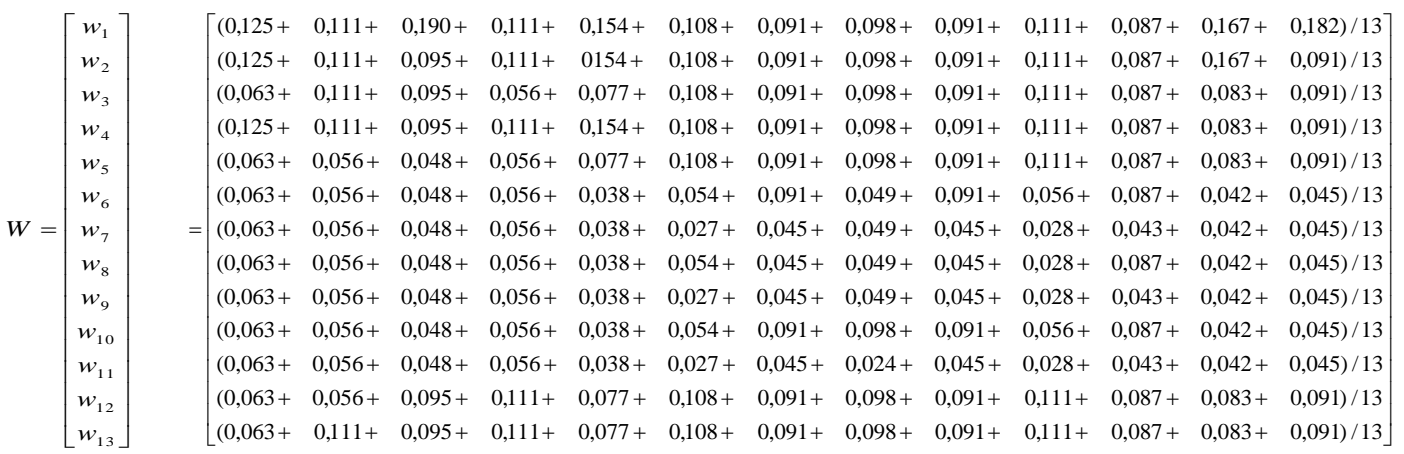
Yukarıdaki sonuçlara göre kriterlerin 'bir yapıyı eleştirel rejyonalist-o yer'e (bölgeye) ait olarak adlandırma' amacı için, birbirilerine göre önem ağırlıkları ve hiyerarşik sıralamaları ise 1'den 10' a kadar olmak üzere Tablo 6'da gösterilmiştir (bazı kriterler aynı puanı almıştır). Göreli önem ağırlığı en yüksek olan kriterin, 'arazinin topoğrafik yapısına uyum' kriteri olduğu tespit edilmiştir. İkinci sırada önem ağırlığına sahip olan kriter ‘doğaya saygılı yaklaşım' kriteri ve üçüncü sırada önem ağırlığına sahip olan kriter 'iklim verilerinin dikkate alınması' kriterinin olduğu tespit edilmiştir.

Kriter önem ağırlığı sıralamasında; dördüncü sırada 'çevredeki yapıların ölçeğine uyum' kriteri, beşinci sırada 'yapının insan ölçeğine yakınlığı' ve 'doğal aydınlatma/gün ışı̆̆ının dikkate alınması' kriterleri, altıncı sırada 'yapının rengi ve dokusuyla birlikte çevre dokuya uyumu' kriteri, yedinci sirada 'yerel malzeme kullanımı' kriteri, sekizinci sırada 'yerel mimari elemanların kullanımı' kriteri, dokuzuncu sırada 'sade biçim diline sahip olma' kriteri, onuncu sirada 'yerel yapım tekniklerinin kullanımı' ve 'fonksiyonunu dışa yansitabilmesi' kriterleri, on birinci ve son sirada 'dokunsal olma' kriteri yer almaktadır. Tutarlılık oranı (CR) 0.014 olarak hesaplanmış olup, 0,10'dan küçük olduğundan karar vericinin kriterlere ilişkin yargılarının tutarlı olduğu görülmektedir.

Tablo 6. 13 kriterin hiyerarşik sıralaması ve önem ağırlık değeri

\begin{tabular}{|c|c|c|}
\hline Önem sırası & İlkeler & Önem Ağırlık Değeri \\
\hline 1 & A1 & 0,125 \\
\hline 2 & A2 & 0,111 \\
\hline 3 & A 4 & 0,104 \\
\hline 4 & D2 & 0,094 \\
\hline 5 & A3 & 0,089 \\
\hline 5 & D1 & 0,089 \\
\hline 6 & A5 & 0,081 \\
\hline 7 & C1 & 0,063 \\
\hline 8 & B1 & 0,060 \\
\hline 9 & B3 & 0,050 \\
\hline 10 & B2 & 0,045 \\
\hline 10 & B4 & 0,045 \\
\hline 11 & C2 & 0,043 \\
\hline \multicolumn{2}{|c|}{ TOPLAM } & $\mathbf{0 , 9 9 9}$ \\
\hline
\end{tabular}

\section{Bulgular}

Çalıșma kapsamında ortaya konulan on üç kriter uzmanlar tarafından test edilip geçerli not almış ve çalışma kapsamında mimari tasarımda "eleştirel rejyonalist-o yer'e (bölgeye) ait tasarım kriterleri” olarak literatüre kazandırılmıştır. Uzmanlara göre bir yapıyı o yer'e (bölgeye) ait olarak adlandırmada en önemli kriterin 'arazinin topoğrafik yapısına uyum' kriteri olduğu tespit edilmiştir. İkinci sırada önem ağırlığına sahip olan ilke 'doğaya saygılı yaklaşım' ilkesi ve üçüncü sırada önem ağırlığına sahip olan ilke 'iklim verilerinin dikkate alınması', ilkesinin olduğu tespit edilmiştir. İlke önem ağırlı̆̆ sıralamasını; dördüncü sırada 'çevredeki yapıların ölçeğine uyum' ilkesi, beșinci sırada 'yapının insan ölçeğine yakınlığı' ve 'doğal aydınlatma/gün ışı̆̆ının dikkate alınması' ilkeleri ile siralama devam etmektedir. Uzmanlar tarafından en az öneme sahip ilkenin 'dokunsal olma' ilkesi olduğu tespit edilmiştir.

Ayrıca çalışma kapsamında ortaya konulan Frampton'ın on maddesinde yer almayan ölçek başlığı altında iki yeni kriterin 'Yapının çevredeki yapıların ölçeğine uyumu' kriteri ve 'yapının insan ölçeğine yakınlığı' kriterinin uzmanlar tarafindan ilk beşte sıralanması çalışmanın bilime olan katkısını vurgulamaktadir.

Yapılan çalışma sonucunda elde edilen veriler ışı̆̆ında, bir mimari ürünü "eleştirel rejyonalist-o yer'e (bölgeye) ait" olarak tanımlamada yeni bir bakıș açısı kazandırılmıştır:

\section{Tartışma ve Sonuç}

Mimarlık, yeryüzünde, 'yer' den başladığı ve o 'yer'de oluştuğu zaman, anlamlı hale gelir. Mimarlık disiplini insanın 'yer' ile kurduğu ilişkiyi yansıtan bir araç konumunda olup tüm süreçte insanın 'yer'e ilişkin algısının değişimi mimarlık anlayışının da değişimine yol açmıştır. İnsanların mekânlarını kurgulama biçimleri değișen sosyo-ekonomik ve toplumsal koşullar ile birlikte değişim geçirmiştir. Endüstri öncesi ve sonrası toplumlarda, mekân ve yer olgularının ele alınışları temelde birbirlerinden farklıdır. Benzer şekilde, çağdaş mimari içinde yer alan modern ve postmodern dönemlerdeki mekân anlayışları da, kendi bağlamlarında birbirlerinden farklıdır.

Sanayi devriminin sonrasında ortaya çıkan modernizmde zaman-mekân anlayışı geleneksel toplumların zaman-mekân kavrayışından farklıdır. Geleneksel toplumlarda üretim ve 'yer' zamanla bütünleşik bir oluşum iken sanayileşme ve kapitalizm; üretim sistemlerini, dolayısıyla zamanı, 'yer'den koparıp nesnelleştirerek ölçülebilir, evrensel, nicel bir değer haline getirmiştir. Modernizmin geleneği, kültürü yerel değerleri reddetmiş, sadece insanların fiziksel ihtiyaçlarını karşılamaya yönelik rasyonel, nesnel ve evrensel kurallarla, 'yer' olgusunu tümüyle hiçe sayan kentler ve mekânlar yaratmaya başlamıştır.

Modernizm mekânın fiziksel gereksinimlere cevap verirken, duygusal beklentilere cevap vermediği ve bunun "insan mekân ilișkisinin tarihsel süreklilik ve yerel değerler içinde incelenerek ortaya yeni bir mekân anlayışı ile çözülebileceği" düşünceleri ile 1980'lerde ortaya çıkan postmodernizm, insan mekân ilişkisini yeniden yorumlamıştır. Ancak postmodern tasarım söylem içinde, yerel ve kültürel 
değerlerin bağlamından koparılarak kullanılması, mimarlığın çoğulcu ortamda farklı zevklere ve tüketim metasına dönüşmesine neden olmuştur. Küresel sermayenin arayıșları ve beklentileri doğrultusunda değişim sürecine giren kentler ve kentsel mekânlar giderek birbirine benzemeye, aynılaşmaya başlamıştır. Simgeler, görüntüler, semboller önemli hale gelerek, yerellik ve özgünlüklerin içi boşaltılmış seyirlik birer meta haline getirilmiştir.

'Yer'e özgü değerlerin yitirilmesi, mimarlığın kendisine özgü yapısını kaybetmesine yol açmış; modernleşme ile başlayan postmodernizm ile devam eden değişim süreçleri sonunda, 'bulunulan' yerden ve 'yaşanan' zamandan bağımsız, her yere ve zamana ait olabilecek mekânlar üretilmeye başlanmıştır. Schulz, yerlerin kendine özgü değerlerine vurgu yaparak, insanın varoluşunu hissetmesinin yerin ruhunu yansitan mimari çevrelerle mümkün olabileceğini ifade etmektedir. Schulz [1] yerin ruhu kavramında, yeri deneyimlemenin, yerin kendine has özelliklerinin açığa çıkarılmasının, mimarlı̆̆ın esas görevi olduğunu aksi halde mimarlığın 'anlamsız' bir iş olacağını söylemektedir [17]. Her yerin kimliğini oluşturan, ona özgü bir karakteri, özelliği olduğunu ve mimarlığın bunu ortaya çıkarması gerekliliğini savunmaktadır. Yerin kimliğinin ne olduğunu anlamak için de, yerin sahip olduğu özellikler tanımlanmalı ve yerin ruhu yeni tasarıma aktarılmalıdır. Çalıșma, yerin ruhunun somutlaștırmanın aracı olarak yer ve yerellik odaklı bir mimarlı öneren 'Eleștirel Bölgeselcilik' kavramını savunmaktadır. Eleştirel Bölgeselcilik, hem kültürel sürekliği sağlamayı, hem de evrensel uygarlık içinde kalabilmeyi amaçlayan yer odaklı bir yaklaşımdır. Eleştirel Bölgeselci yaklaşımda, iklim, ışık gibi bölgesel nitelikleri, kültüre ilişkin verileri, mimarlığın tektonik ifadesi ile birleştirilir. Böylece sahnesel olmayan, insanın algılayabildiği ve hissedebildiği, bulunduğu yere ait bir mimarlık oluşur.

Çalışma kapsamında yapılan literatür araştırması sonucunda, eleştirel bölgeselcilikle ilgili çalıșmaların genellikle teorik düzeyde kaldığı tespit edilmiştir. Eleştirel bölgeselciliğin mimari tasarım kriterlerinin eksik ve yetersiz olduğu belirlenmiş, konuyla ilgili çalışma yapılmadığı tespit edilmiştir. Bu çalışmayla bu boşluk doldurulmuş "eleştirel rejyonalist tasarım kriterleri" ortaya konulmuş ve bu kriterlerin geçerliliği, öncelik sırası uzmanlar tarafından belirlenmiştir.

Elde edilen veriler öngörülen hedeflere ulaşmada tasarımcı için yol gösterici bir rehber niteliği taşımaktadır. Çalışma kapsamında geliştirilen eleştirel bölgesel tasarım kriterlerinin mimari tasarım sürecinde aktif bir şekilde kullanılmasıyla elde edilen mimari tasarımlar yapay donanımlara ihtiyaç duymaksızın bulunduğu çevre ile bütünleşerek gerçeklik duygusu yaratacaktır. Çünkü mimari tasarım, ancak çevresini saran, mikro ölçekten makro ölçeğe kadar sosyal, kültürel, fiziksel ve teknolojik olarak ontolojik bütünlüğü sağlayıp 'yer'le ilişkisini başarılı kurduğu ölçüde yaşamaktadır.

\section{Teşekkür}

$\mathrm{Bu}$ çalışma, Selçuk Üniversitesi Fen Bilimleri Enstitüsü Mimarlık Anabilim Dalında Prof. Dr. Ahmet ALKAN'ın danıșmanlığında tamamlanan Emine YILDIZ KUYRUKÇU'nun 'Mimari Tasarımda Eleștirel Bölgeselci Yaklaşımın Gelişim Süreci: Kenneth Frampton Illkeleri Bağlamında Bir Değerlendirme' isimli Doktora Tezinden üretilmiștir.

\section{Kaynakça}

[1] Norberg-Schulz, C. 1980. Genius loci: towards a phenomenology of architecture. Rizzoli, New York.

[2] Abel, C. 1997. Architecture and Identity: Responses to Cultural and Technological Change. Architectural Press, Oxford, United Kingdom

[3] Corbusier, L. 1952. Towards A New Architecture. The Architectural Press, London, 7-126.

[4] Orhon, T., Yırtıcl, H. 1995. Postmodernizm, Gelenek ve Olumlamanın Kolaycılığı. Arredamento architecture (70), 132-134.

[5] McLeod, M. 1989. Architecture and politics in the Reagan era: From postmodernism to deconstructivism. Assemblage (8), 23-59.

[6] Venturi, R. 1977. Complexity and contradiction in architecture. The museum of modern art, New York.

[7] Harvey, D. 1997. Postmodernliğin Durumu. Translated by Sungur Savran, Metis publications.

[8] Allen, B. L. 2007. On Performative Regionalism. in Canizaro, Vincent B. (eds.), Architectural regionalism: collected writings on place, identity, modernity, and tradition, Princeton Architectural Press, New York, 421-426.

[9] Canizaro, V. B. 2007. Introduction. in Canizaro, V. B. (eds.), Architectural Regionalism: Collected Writings on Place, Identity, Modernity, and Tradition, Princeton Architectural Press, New York, 17-33.

[10] Tzonis, A., Lefaivre, L. 1985. The Grid and the Pathway: An Introduction to the Work of Dimitris and Suzana Antonakakis in the Context of Greek Architectural Culture. in Frampton, K. (eds.), Atelier 66: The Architecture of Dimitris and Suzana Antonakakis.

[11] Tzonis, A., Lefaivre, L. 1996. Why Critical Regionalism Today?. in Nesbitt, K. (eds.), Theorizing a New Agenda for Architecture: An 
Anthology of Architectural Theory 1965-1995, Princeton Architectural Press.

[12] Frampton, K. 1983. Towards a Critical Regionalism: Six Points for an Architecture of Resistance. in Foster, H. (eds.), The AntiAesthetic: Essays on Postmodern Culture, Bay Press, Post Townsend, Washington, 16-30.

[13] Frampton, K. 1983 Prospects for a Critical Regionalism. Perspecta, 20, 147-162.

[14] Frampton, K. 1992. Critical regionalism: Modern architecture and cultural identity. in Frampton K. (eds.), Modern architecture: A critical history, Thames \& Hudson world of art, 314-327.
[15] Saaty, T. L. 1994. Fundamentals of decision making and priority theory with the analytic hierarchy process. Vol. VI, Universitas Pittsburgh, USA.

[16] Saaty, T. 2005. The analytic hierarchy and analytic network processes for the measurement of intangible criteria and for decision-making, Multiple criteria decision analysis: state of the art surveys, 345-405.

[17] Van Nes, A. 2008. The Heaven, the Earth and the Optic Array: Norberg-Schulz's Place Phenomenology and its Degree of Operationability, Footprint. 